\title{
RESPONSE TO THE HL - 69 SOIL RESISTIVE MOISTURE SENSOR IN DIFFERENT SUBSTRATES
}

\section{RESPOSTA DO SENSOR RESISTIVO DE UMIDADE DO SOLO HL - 69 EM DIFERENTES SUBSTRATOS}

\author{
Daniela Andreska da Silva ${ }^{1}{ }^{\mathbb{D}}$, Rebecca Tavares Bessa ${ }^{2}$, Alan Bernard Oliveira de Sousa ${ }^{3}{ }^{\oplus}$, \\ Adunias dos Santos Teixeira ${ }^{4}$
}

\footnotetext{
${ }^{1}$ Master's student of the Postgraduate Program in Agricultural Engineering, Federal University of Ceará (UFC), Fortaleza, CE, Brazil.

${ }^{2}$ Agricultural Engineer, Federal University of Ceará (UFC), Fortaleza, CE, Brazil

${ }^{3}$ Professor Dr. at the Department of Agricultural Engineering at the Federal University of Ceará (UFC), Fortaleza, CE, Brazil.

${ }^{4}$ Professor PhD at the Department of Agricultural Engineering at the Federal University of Ceará (UFC), Fortaleza, CE, Brazil.
}

\begin{abstract}
The objective of this work was to evaluate the response of the soil moisture resistive sensor HL-69 to different substrates. The study was split into two experiments. These were conducted at the Hydraulics and Irrigation Laboratory of the Agricultural Engineering Department of the Federal University of Ceará. Forty polyethylene vases with a capacity of $1030 \mathrm{~mL}$ were used, arranged on a benchwork. The treatments corresponding to the substrates were T1 (soil + commercial substrate (1: 1)); T2 (soil + hydroretainer (2 g kg-1); T3 (soil) and T4 (commercial substrate), with ten replicates per treatment. The readings of the Hl-69 sensors were carried out simultaneously with the weighing of the vases on an analytical scale. According to the most promising response, the second experiment was started with the adoption of the T3 treatment. The readings carried out in this work followed two different methodologies: Firstly, readings of the saturation condition until low moisture (wet-dry) were obtained, and later they were obtained from the low moisture point to saturation (dry-wet). The Hl-69 sensor shows poor performance in determining the water content in the adopted substrates, showing better performance for the T3 treatment. The methodology that obtained the best adjustment of the data was the soil readings in the wetting process (dry-wet).
\end{abstract}

Keywords: Arduino, automation, calibration, soil saturation.

RESUMO: Objetivou-se avaliar a resposta do sensor resistivo de umidade do solo HL-69 para diferentes substratos. O estudo foi dividido em dois experimentos. Estes foram conduzidos no Laboratório de Hidráulica e Irrigação do Departamento de Engenharia Agrícola da Universidade Federal do Ceará. Foram utilizados 40 vasos de polietileno com capacidade de $1030 \mathrm{~mL}$, dispostos sobre bancada. Os tratamentos referentes aos substratos foram T1 (solo + substrato comercial (1:1)); T2 (solo + hidroretentor (2 g kg-1); T3 (solo) e T4 (substrato comercial), sendo dez repetições por tratamento. As leituras dos sensores Hl-69 foram obtidas simultâneas à pesagem dos vasos em balança analítica. Conforme obtenção da resposta mais promissora deuse início ao segundo experimento com adoção do tratamento T3. As leituras realizadas seguiram duas metodologias diferentes: Primeiramente obtiveram-se leituras desde condição de saturação até baixa umidade (úmido-seco) e posteriormente foram obtidas leituras do ponto de baixa umidade até saturação (seco-úmido). O sensor Hl-69 apresentou baixo desempenho na determinação do teor de água nos substratos avaliados, apresentando melhor desempenho para o tratamento T3. A metodologia que obteve melhor ajuste dos dados foi das leituras do solo em processo de umedecimento (seco-úmido).

Palavras-chave: saturação do solo, calibração, automação, arduino. 


\section{INTRODUCTION}

The most used methods for irrigation management use atmospheric data or data related to soil moisture. For the direct determination of soil moisture, despite the 24hour period or more to obtain the result, the standard greenhouse method is the most used (MIRANDA; PIRES, 2001

The method consists of obtaining a soil sample and through weighing, where the mass of water is related to the mass of solids in the sample, the moisture can be obtained based on mass or volumetric moisture (LEÃO et al., 2007). The main indirect methods for obtaining soil moisture are based on soil characteristics that vary with its moisture, requiring prior calibration (LEÃO et al., 2007).

A study such as the one by Freitas et al. (2012) who observed measurements involving electricity (voltage, current, frequency, resistance, capacitance, dielectric properties) can be used, either individually or in combination, to obtain information about which medium electrons move. An example easily found on the market are resistive sensors for the determination of soil moisture.

The advantages of using resistive sensors to determine soil moisture correspond to their accessibility to manipulation, low acquisition cost, and high availability in the market (BENEDÍ et al, 2005). However, each medium in which moisture is desired needs to be calibrated according to the type of sensor and its sensitivity to the characteristics of that medium. This fact is evident when hydroretaining polymers are used in the soil.

Azevedo et al. (2002) and Câmara et al. (2011) state that the addition of hydrogel to the soil contributes to seed germination, development of the root system, plant growth and development, reduction of water losses through percolation, in addition to reducing nutrient losses through leaching. Therefore, this condition is an important alternative for the low availability of water in the soil (PREVEDELLO; LOYOLA, 2007).

It is observed that, in order to use a sensor for irrigation management, its evaluation in the environment in which the humidity values are to be obtained is fundamental. Thus, what is always taken into account when analyzing a sensor is the speed and response time (CRUZ et al., 2010), which according to Oliveira (1999) is a very important factor, since the purpose is to obtain sensors that present fast response time to soil drying, in order to determine the new irrigation.

Thus, the objective of this study was to evaluate the response of the HL-69 soil moisture sensor in treatments referring to $\mathrm{T} 1$ substrates (soil + commercial substrate); T2 (soil + hydro- -retainer (2 g kg-1); T3 (soil), and T4 (commercial substrate).

\section{MATERIAL AND METHODS}

The work was split into two experiments, the first being carried out at the Hydraulics Laboratory, Department of Agricultural Engineering (DENA), Federal University of Ceará (UFC), Campus do Pici, within the geographic coordinates $3^{\circ} 45^{\prime}$ of latitude $\mathrm{S}$ and $38^{\circ} 33^{\prime}$ longitude $\mathrm{W}$, altitude 19 $\mathrm{m}$, where the sensor response was tested on different types of substrates, from September to December 2019.

For circuit assembly and sketch design, an Arduino prototyping platform was used. One of the analog ports was used to obtain data (0 to 1023) from the Hl-69 resistive soil moisture sensor. The data was shown on a serial computer monitor through a USB connection to the Arduino board.

Forty polyethylene pots with a capacity of $1030 \mathrm{~mL}$ were used, placed on a ceramiccovered workbench. The treatments corresponding to the substrates were T1 (soil + commercial substrate $(1: 1)$ ); T2 (soil + hydro-retainer (2 g kg-1); T3 (soil) and T4 (commercial substrate), with ten replicates per treatment.

The commercial substrate used consisted of peat and carbonized rice husk, with a density of $260 \mathrm{~kg} \mathrm{~m}-3$ and a water retention capacity (WRC) of $60 \%$. The soil used in the experiment is classified as Quartzarenic 
Neosol (Table 01) and was collected in the experimental field of Embrapa Agroindústria Tropical, in Pacajús, Ceará. The hydroretaining polymer used was the comercial brand Polyter ${ }^{\circledR}$, incorporated and homogenized while still dry in the soil in the proportion of 2 grams of Hydrogel for $\mathrm{e}$ ach kilogram of soil, considering the range recommended by the manufacturer. The accommodation of the soil in the pots was carried out manually.

Table 1. Chemical characteristics of the soil used in the experiment.

\begin{tabular}{|c|c|c|c|c|c|c|c|c|c|c|c|c|}
\hline $\mathrm{P}$ & $\mathrm{OM}$ & $\mathrm{pH} \mathrm{H}_{2} \mathrm{O}$ & $\mathrm{K}^{+}$ & $\mathrm{Ca}^{2+}$ & $\mathrm{Mg}^{2+}$ & $\mathrm{Na}^{+}$ & $\mathrm{H}+\mathrm{Al}$ & $\mathrm{Al}^{3+}$ & SB & $\mathrm{CEC}$ & $\mathrm{V}$ & $\overline{\mathrm{m}}$ \\
\hline $\mathrm{mgdm}^{-3}$ & $\mathrm{~g} \mathrm{~kg}^{1}$ & & $-\cdots$ & ---- & ------ & $\mathrm{ol}_{\mathrm{c}} \mathrm{dl}$ & -3------- & ------ & --- & & $--\%-$ & \\
\hline 9.4 & 6.2 & 5.5 & 1.2 & 11 & 5 & 0 & 21.8 & 0.4 & 18 & 39 & 45 & 2 \\
\hline
\end{tabular}

The methodology used for the analysis of $\mathrm{P}, \mathrm{K}+, \mathrm{Na}+$ was Mehlich 1, Walkley-Black was used for $\mathrm{OM}$ analysis, for $\mathrm{pH}$ in water analysis - soil ratio was used water $(1: 2.5)$, for $\mathrm{Ca} 2+, \mathrm{Mg} 2+$ and $\mathrm{Al1}+$ was used KCL $1 \mathrm{~mol} / \mathrm{L}$ and for $\mathrm{H}+\mathrm{Al}(\mathrm{CH} 3 \mathrm{COO}) 2 \mathrm{Ca} . \mathrm{H} 2 \mathrm{O} 0.5 \mathrm{~mol} / \mathrm{L}$ $\mathrm{pH}$ 7.1-7.2 was used. Na+ was not analyzed.

The pots were subjected to saturation until reaching maximum retention capacity, then the moisture data were collected, where the treatments were successively submitted to the saturation and drying process. The pots were weighed on an analytical balance to obtain the wet mass (Equation 01) simultaneously with the reading of the Hl-69 sensor, installed vertically in the center of each pot. For the order in which the readings were obtained, the experimental design in randomized blocks was adopted.

$\mathrm{Mu}=\mathrm{Ma}+\mathrm{Ms}$

Where: $\mathrm{Mu}$ - wet soil mass (g); $\mathrm{Ma}-$ water mass $(\mathrm{g})$; Ms - solid mass $(\mathrm{g})$. At the end of the experiment, the solid material from each pot was transferred to aluminum containers and placed in an oven at $110^{\circ} \mathrm{C}$ for 48 hours. Then, the samples were weighed, and the mass of solids was obtained (Equation 02).

$\mathrm{U}=(\mathrm{Mu}-\mathrm{Ms}) / \mathrm{Ms}$
Where: $\mathrm{U}$ - moisture, on a weight basis (g g-1); Mu - wet soil mass (g); Ms - mass of solids (g).

The treatment that showed the most promising response, among the four observed in experiment 1, was adopted in the second experiment, in which, out of the total of ten replicates analyzed in treatment T3 (soil), five pots $\mathrm{s}$ were used for sensor evaluation in different moistening methodologies.

In the center of each pot, an Hl-69 sensor was positioned vertically, where the readings taken by the sensors were monitored through an LCD display. For the moisture readings carried out in each pot, the 15-minute permanence of the Hl-69 sensors in the soil was standardized, and then they were then removed, due to the limited availability for collecting data from the analyzed samples.

The IDE (Integrated Development Environment) used in this work was the Arduino board software, where the algorithm was developed and later transferred to the Arduino Nano's internal memory. After the Arduino Nano's analog-digital converter mapped the voltages (between 0 and the operating voltage $(5 \mathrm{~V})$ ) and converted them into integer values (0-1023), the readings were sent to the Arduino's IDE and then visualized employing the serial monitor (Figure 1). 


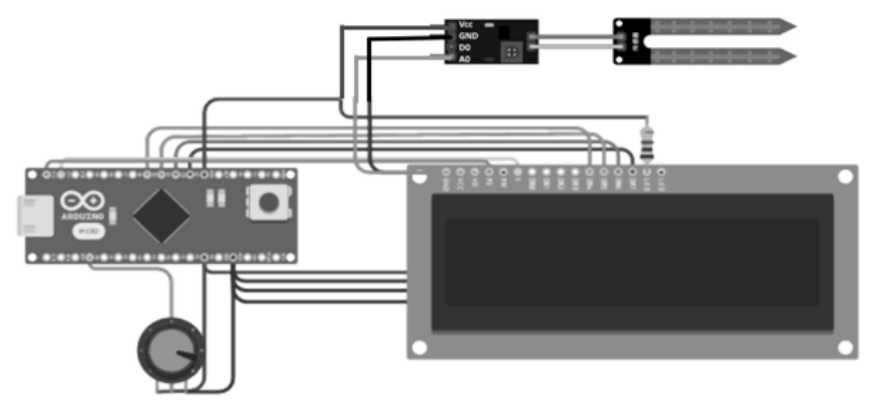

Figure 1. Assembly sketch used to collect substrate moisture data and displayed on an LCD screen. Source: The author

In the second experiment, two substrate saturation methodologies were used. In the first methodology, water was added to the top of the pot with the aid of a container, until the total soil condition of soil saturation was visually verified, obtaining readings from saturation condition to low humidity (wetdry).

In the second methodology, the saturation occurred in an ascending way, through capillary action, in which the pots were placed on a tray with a layer of water, obtaining readings from the point of low humidity to saturation (dry-wet). The sensors were installed and maintained in the respective pots until the end of the experiment.

The models were Evaluated and classified based on the coefficient of determination (R2), mean bias error (MBE) (Equation 03), in the square root of the mean square error (RMSE) (Equation 04) and index of confidence, $\mathrm{c}$ (Equation 05).

$M B E=\frac{\sum_{i=1}^{n}\left|P-O_{i}\right|}{N}$

Where: $\mathrm{n}$ - the number of observations; $\mathrm{Pi}$ - values estimated by the sensors $(\mathrm{i}=1$, $2, \ldots ., \mathrm{n})$; Oi - values calculated based on the gravimetric method.

$\operatorname{RMSE}=\sqrt{\frac{\sum_{i=1}^{n}\left(P_{i}-O_{i}\right)^{2}}{n}}$

Where: RMSE - square root mean square error; Pi - estimated values based on sensor readings; Oi - values calculated based on the gravimetric method; $\mathrm{n}$ - number of observations.

$$
c=r \times d
$$

Where: "c" - confidence index; "r" coefficient of determination; "d" - Willmott's agreement index (1981), represented by the following equation (06).

$\mathrm{d}=1-\left[\sqrt{\frac{\sum_{i=1}^{n}\left(P_{i}-O_{i}\right)^{2}}{\sum_{i=1}^{n}\left(\left|P_{i}-\bar{O}\right|+\left|\overline{0}_{i}-\overline{0}\right|\right)^{2}}}\right]$

Where: Ōi - values calculated based on the gravimetric method; $\overline{\mathrm{O}}$ - mean of measured values.

Statistical analyses were performed using the Microsoft Excel ${ }^{\circledR}$ program. In the root mean square error and confidence index classifications, the classification proposed respectively by Fares et al. (2011) and Camargo and Sentelhas (1997) were used.

\section{RESULTS AND DISCUSSION}

1.1. First experiment: study of the relationship between electric tension and moisture

Linear regression curves were fitted for the four monitored treatments (Figure 2 ). The regressions were significant at $5 \%$ by the $\mathrm{F}$ test. In all treatments, the behavior of the Hl-69 sensor data tended to a decreasing linear fit, showing a reduction in electric tension values as soil moisture was incremented. 

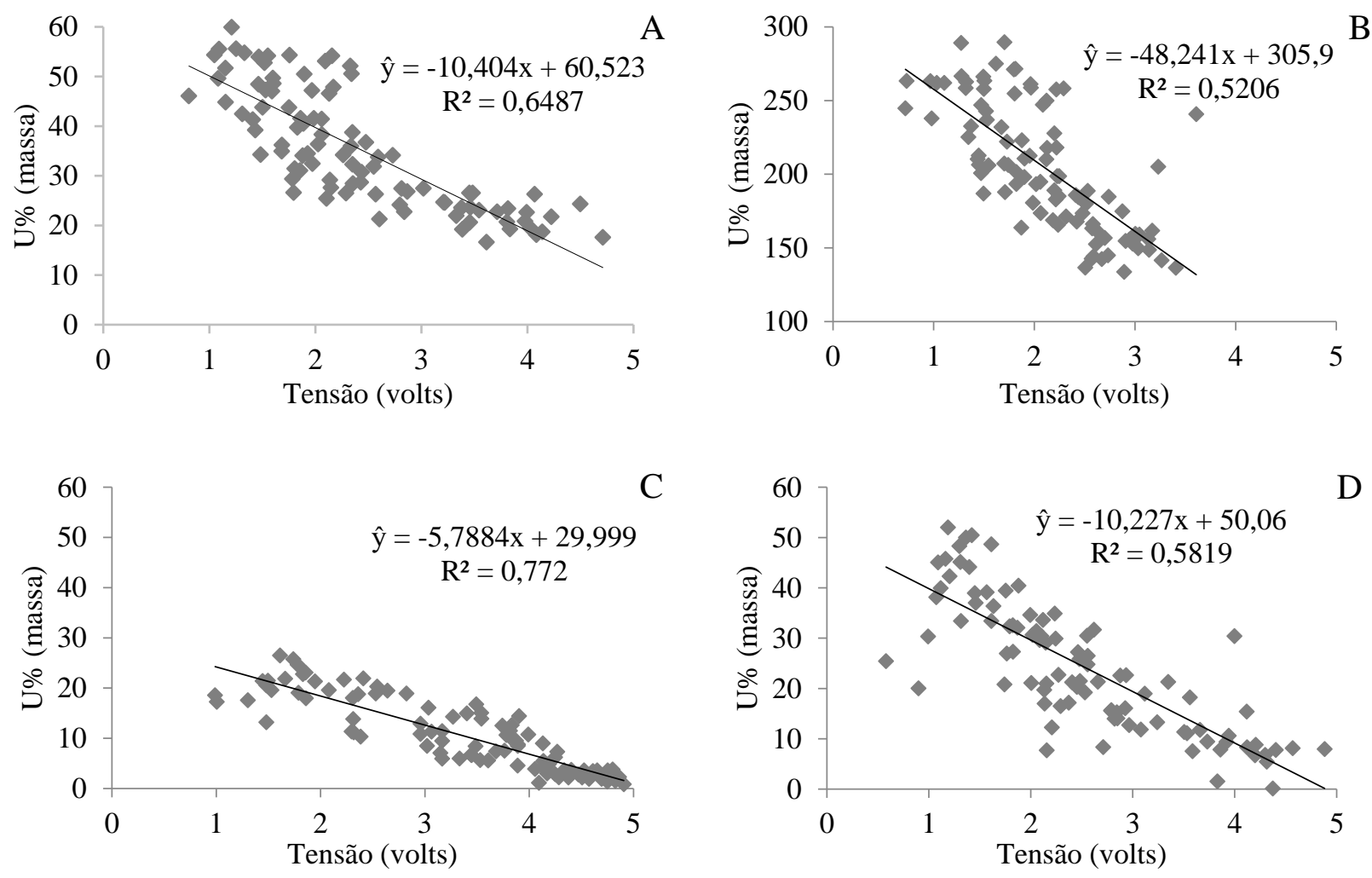

Figura 2. Regression curves according to the electric tension (volts) obtained with the Hl-69 sensor and data on the moisture (U) in the substrates: (A) soil + commercial substrate; (B) soil + hydro-retainer; (C) soil; and (D) commercial substrate.

The coefficients of determination (R2) showed values of $0.64,0.52,0.77$, and 0.58 , in treatments $\mathrm{T} 1, \mathrm{~T} 2, \mathrm{~T} 3$, and $\mathrm{T} 4$, respectively (Figure 2). Different results from those obtained by Jimenéz et al. (2019) in which R2 was greater than 0.90 when calibrating the Yl69 sensor in two soils, classified as Yellow Latosol and Regolithic Neosol, stored in 5-L pots. Greater variability of readings can be observed in wetter soil conditions. This fact is more evident in T3 where the data show less dispersion when the soil was dry and greater dispersion when it was wet. This is explained by the fact that the soil has a larger contact surface than other treatments, in addition to the moisture of a sample directly influencing the resistivity of the sensor. According to Tan et al. (2019) the electrical resistivity of the soil decreases exponentially as water saturation increases. In general, similarities can be observed among the results obtained by treatments $\mathrm{T} 1$ and $\mathrm{T} 4$ (Figures $2 \mathrm{~A}$ and 2D, respectively), due to the intrinsic characteristics of the substrate. In the Sandysoil treatment (T3), it was observed strong linearity in the graph, demonstrating an accentuated loss of moisture caused by the low water retention capacity in sandy textured soils (Figure 2C).

In addition, this treatment also showed the best coefficient of determination and the smallest dispersion of data, both among the repetitions and in comparison, with the other treatments, thus justifying the use of this treatment in the second experiment.

Concerning T2, the curve already demonstrates an expressive variation in water loss, however, greater retention capacity resulting from the high water retention capacity of the hydro-retaining polymers. According to Pizzeta et al. (2017) as it is a resistive sensor, the greater the amount of water available in the soil, the lower the measurement of electrical resistance.

Data on the moisture through the gravimetric method showed different values 
when compared to the other treatments, with a variation in U (mass)\% from 120 to 300 (Figure 2B). According to Navroski et al. (2016), this behavior is caused by the potential of the hydro-retainer in absorbing water in more than 100 times its mass, resulting in its controlled availably.

The RMSE values obtained in this experiment had the accuracy classified as very weak (RMSE > 0.1) for all treatments (Table $2)$, therefore, inaccuracy of the Hl-69 sensor in data acquisition was observed according to the classification by Fares et al. . (2011). The confidence or performance indices (c) showed a significant amplitude, ranging from very poor to excellent $(0.40 \leq \mathrm{c}>0.85)$, according to the classification proposed by Camargo and Sentelhas (1997), revealing the low reliability of the sensor in the content estimation of water for the treatments. Only the T3 treatment showed a considerably better performance when compared to the others (Table 2).

Table 2. Performance indicators of the linear model for calibration of the Hl-69 moisture sensor in the first experiment.

\begin{tabular}{cccccc}
\hline Treatment & RMSE & Classification & $\mathrm{c}$ & Classification & $\mathrm{R}^{2}$ \\
& & & & & \\
\hline T1 & 7.13 & Very weak & 0.54 & Very poor & 0.6487 \\
T2 & 170.28 & Very weak & 0.17 & Poor & 0.5206 \\
T3 & 16.32 & Very weak & 0.37 & Poor & 0.7772 \\
T4 & 13.23 & Very weak & 0.41 & Bad & 0.5819
\end{tabular}

RMSE: root mean square error; c: confidence index; $\mathrm{R}^{2}$ : coefficient of determination.

According to Ruelle and Laurent (2008), to successfully obtain the data from the sensors, it is important to avoid air gaps between the stem and the soil during their installation. This statement corroborates the analysis of the results, as, in this work, the sensors were installed and removed successively at the end of each reading, becoming a possible source of errors. Furthermore, Tan et al. (2019), working with the Hl-69 sensor, also elucidate that the reaction between soil moisture and $\mathrm{O} 2$ reduces the lifetime of the sensor due to rod oxidation.

1.2. Second experiment: evaluation of the sensor to "T3" treatments in different wetting methodologies

In the evaluation of the reading carried out by the Hl-69 sensors to detriment of the methodologies adopted for wetting, it is possible to observe the decrease in the tension as the humidity increases (Figure 3). The curves corresponding to the data obtained under wetting conditions (dry-wet), represented by the symbol " ", indicate satisfactory results, showing an R2 greater than 0.90 .

Linear regression curves were fitted for the data obtained from the wet-dry substrate saturation methodology, the dry-wet substrate saturation methodology, and the combination of the data from the two methodologies (s + u), symbolized by " ". The curves for wet-dry methodology represented by the symbol " ", did not show a good fit, revealing R2 values of less than 0.90 (Table 03). This fact may be explained by the fact that in this methodology the substrate closer to the base of the pot and consequently further from the sensor is wetted first. 
Response to the HL - 69 soil resistive moisture sensor in different substrates

A
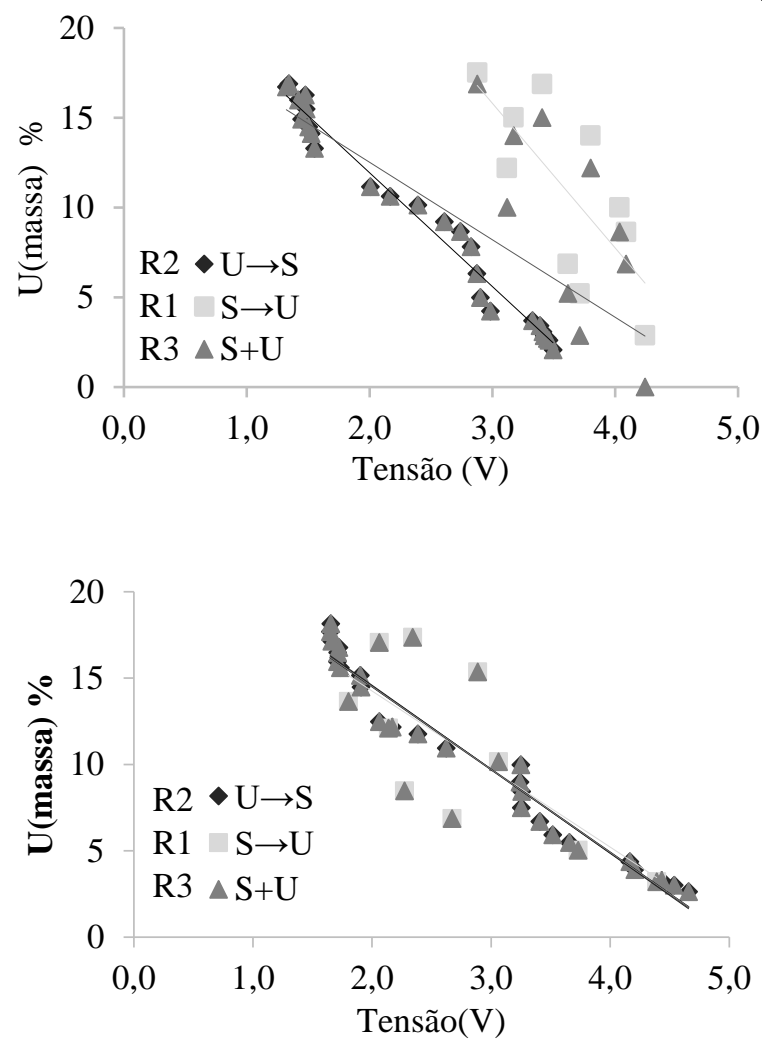

$\mathrm{C}$
B
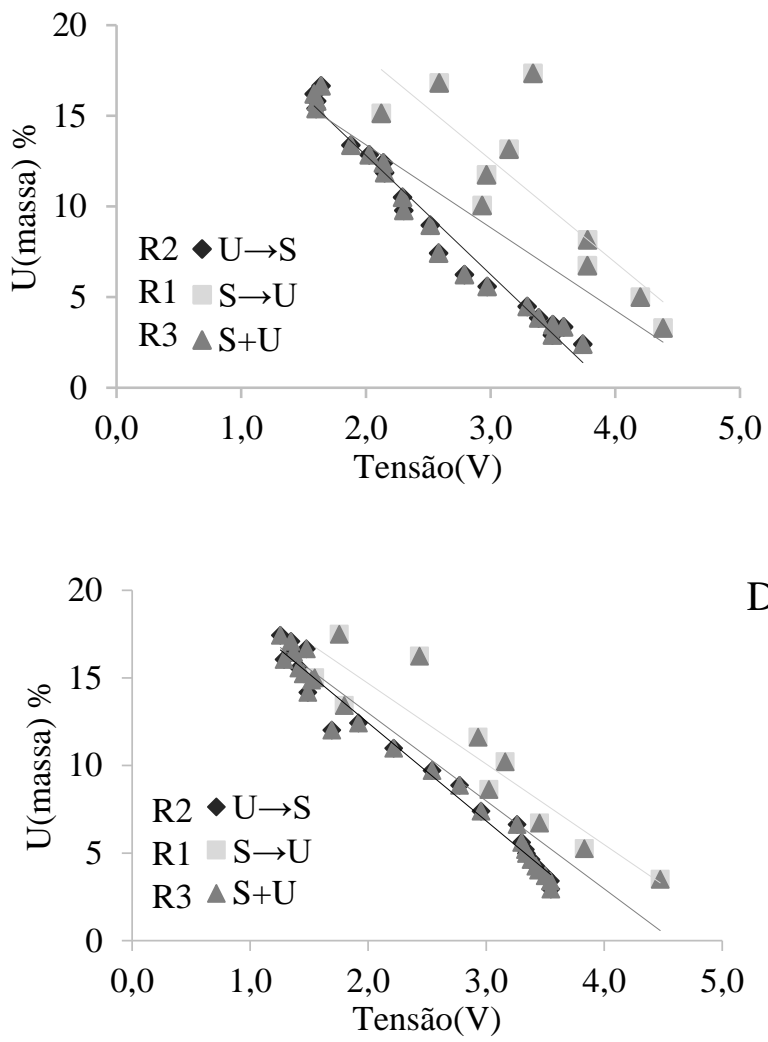

Figura 3. Response of Hl-69 (volts) sensor according to the methodology of soil saturation in four replicates (A, B, C, and D).

Table 3. Equations and coefficient of determination of figures 3A, 3B, 3C e 3D.

\begin{tabular}{|c|c|c|}
\hline Treatment & Eq. & $\mathrm{R}^{2}$ \\
\hline T3R1 & $=-8.0577 x+39.975$ & 0.5354 \\
\hline T3R2 & $=-6.338 x+24.611$ & 0.9779 \\
\hline T3R3 & $=-4.3166 x+21.151$ & 0.5562 \\
\hline T3R1 & $=-5.6705 x+29.594$ & 0.6769 \\
\hline T3R2 & $=-6.5706 x+25.96$ & 0.9744 \\
\hline T3R3 & $=-4.5693 x+22.543$ & 0.568 \\
\hline T3R1 & $=-4.8053 x+24.125$ & 0.8546 \\
\hline T3R2 & $=-4.8702 x+24.328$ & 0.9639 \\
\hline T3R3 & $=-4.5192 x+23.291$ & 0.5371 \\
\hline
\end{tabular}


Silva et al.

\begin{tabular}{ccc}
\hline T3R1 & $=-4.6008 \mathrm{x}+23.886$ & 0.8533 \\
T3R2 & $=-5.0197 \mathrm{x}+23.037$ & 0.8726 \\
T3R3 & $=-5.5961 \mathrm{x}+23.624$ & 0.9791 \\
\hline
\end{tabular}

Eq.: graph equation; $\mathrm{R}^{2}$ : coefficient of determination.

The analysis of RMSE values (Table 4) showed very weak accuracy for all repetitions (RMSE > 0.1). It can be observed that the confidence indices (c) in the data corresponding to the wet-dry condition (drying) showed an excellent classification (> $0.85)$.

However, in a dry-wet condition (wetting), the data do not present a satisfactory classification.

Table 4. Performance indicators of the linear model for calibration of Hl-69 moisture sensor in different soil saturation methodologies.

\begin{tabular}{|c|c|c|c|c|c|}
\hline & Treatment & RMSE & Classification & c & Classification \\
\hline \multirow{5}{*}{ WET- DRY (U) } & T3R1 & 0.7801 & Very weak & 0.9600 & Excellent \\
\hline & T3R2 & 0.7721 & Very weak & 0.9543 & Excellent \\
\hline & & & & & \\
\hline & T3R3 & 0.9758 & Very weak & 0.9372 & Excellent \\
\hline & T3R4 & 0.7993 & Very weak & 0.9602 & Excellent \\
\hline \multirow{4}{*}{ DRY-WET (S) } & T3R1 & 3.2445 & Very weak & 0.4382 & Poor \\
\hline & T3R2 & 2.6560 & Very weak & 0.5767 & Very poor \\
\hline & T3R3 & 3.2271 & Very weak & 0.437 & Poor \\
\hline & T3R4 & 1.7355 & Very weak & 0.7812 & Very good \\
\hline \multirow{5}{*}{$\mathrm{U}+\mathrm{S}$} & T3R1 & 3.9020 & Very weak & 0.3419 & Poor \\
\hline & T3R2 & 3.1757 & Very weak & 0.4684 & Poor \\
\hline & & & & & \\
\hline & T3R3 & 1.9167 & Very weak & 0.7774 & Very good \\
\hline & T3R4 & 1.7751 & Very weak & 0.8052 & Very good \\
\hline
\end{tabular}

RMSE: root mean square error; c: confidence index; $\mathrm{R}^{2}$ : Coefficient of determination

The addition of all the data in a single graph resulted in a linear equation where less dispersion is observed at the beginning of the curve, indicating a better soil adhesion to the sensor and, consequently, a mor e consistent reading (Figure 4). However, it is possible to see a greater dispersion of data in the middle section. 


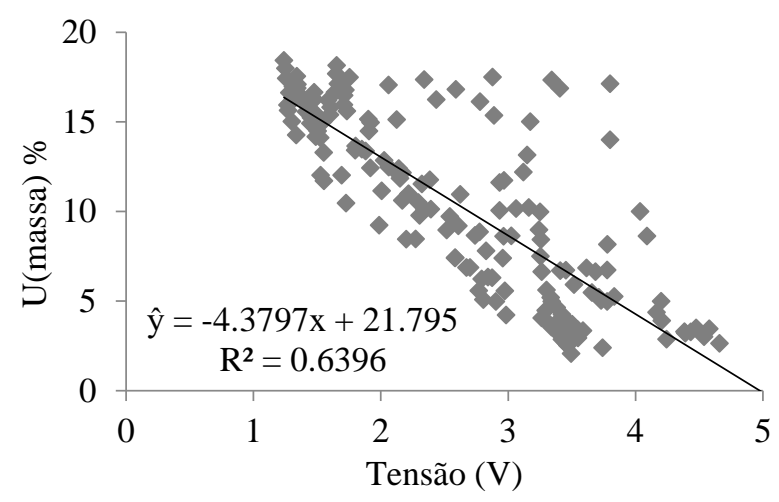

Figure 4. Response of Hl-69 sensor (volts) according to the soil moisture for treatment T3 and different methodologies for soil wetting.

It can be seen in Table 5 that the classification of the Hl-69 sensor to determine the humidity of the studied treatment was considered weak (RMSE > 0.1). The same was observed for the confidence index, where the estimate of soil moisture is classified as poor (0.51 to 0.60$)$, showing, in general, the low reliability of the sensor for the conditions established in this work. Macedo et al. (2010) in evaluating the performance of an irrigation system through soil water tension using Watermark ${ }^{\circledR}$ 200SS model sensors, found that the system showed an over and low application, affecting crop yield. The variant behavior can be imposed on several factors, among them the inadequate installation of the sensor in the soil, the interaction with the environment, and the variability of the uniformity of the soil stand out (MACEDO et al., 2010).

Table 5. Performance indicators of the linear model for calibration of the moisture meter at the end of the experiment.

\begin{tabular}{llllll}
\hline Treatment & RMSE & Classification & $\mathrm{c}$ & Classification & $\mathrm{R}^{2}$ \\
T3 & 3.0565 & Very weak & 0.5314 & Very poor & 0.6345
\end{tabular}

RMSE: root mean square error; C: confidence index; $\mathrm{R}^{2}$ : Coefficient of determination.

As the contact area of the sensor with the substrate is limited, it is necessary to use a greater number of evaluations and/or sensors over the soil profile, to obtain greater representation of its moisture (GOMES et al., 2017). Furthermore, as it is a low-cost material, the quality may also have interfered with the readings. However, a difference in the sensor response can be observed as a function of the substrate, revealing the need to study work. Therefore, there is a need to calibrate the sensor for each type of soil, especially when a high degree of precision is needed for the determination of soil moisture (MIRANDA et al., 2007). data adjustments for each substrate. Canafistula et al. (2005) elucidate that the choice of data by analyzing the behavior of the sensor is significant for the correct performance of the automated irrigation system. In a general analysis, the sensor did not obtain indicators with satisfactory performance for the estimation of soil moisture in any of the treatments used in this

\section{CONCLUSION}

The data obtained in this work allowed us to observe the importance of studying the response of the resistive sensor in substrates. 
The Hl-69 sensor obtained better moisture readings for the sandy soil.

Based on the different responses of the sensor to the different assessed treatments, the adjustment of the data must be obtained for each substrate that the Hl-69 sensor is to be used to obtain the water content.

Also, based on the performance indicators of the Hl-69 sensor for the assessed substrates, the moisture estimated by it was not accurate.

\section{REFERENCES}

AZEVEDO, T. L. F.; BERTONHA, A.; GONÇALVES, A. C. A.; TAS, P. S. L., FRIZZONE, J. A. Níveis de polímero superabsorvente, frequência de irrigação $\mathrm{e}$ crescimento de mudas de café. Acta Scientiarum, Maringá, v. 24, n. 5. p. 1239 1243, 2002. DOI:10.4025/actasci agron.v24i0.2271.

CÂMARA, G. R.; REIS, D. F.; ARAÚJO, G. L.; CAZOTTI, M. M.; DONATELLI JUNIOR, E. J. Avaliação do desenvolvimento do cafeeiro Conilon robusta tropical mediante uso de polímeros hidro-retentores e diferentes turnos de rega. Enciclopédia Biosfera, Goiânia, v. 7, n. 13; p. 135 - 146, 2011.

CAMARGO, A. P., SENTElHAS P. C. Avaliação do desempenho de diferentes métodos de estimativas da evapotranspiração potencial no Estado de São Paulo, Brasil. Revista Brasileira de Agrometeorologia, Santa Maria, v. 5, n. 1, p. 89-97, 1997.

CANAFÍSTULA, F. J. F.; TEIXEIRA, A.S.; RIBEIRO, R. S. F; GONDIM, R.S.; MIRANDA, F. R. Controle de malha fechada para irrigação de precisão. Irrigação e Tecnologia Moderna. Brasília, v. 67, p. 8285, 2005.

Cruz, T. M. L.; Texeira, A. S.; Canafístula, F. J. F.; Santos, C. C.; Oliveira, A. D. S.; Daher, S. Avaliação de sensor capacitivo para o monitoramento do teor de água do solo.
Engenharia Agrícola, v.30, p. 33-45, 2010. DOI: $10.1590 / \mathrm{s} 0100-69162010000100004$.

FARES, A.; ABBAS, F. MARIA, D. MAIR, A. Improved Calibration Functions of Three Capacitance Probes for the Measurement of Soil Moisture in Tropical Soils. Sensors, Basel, v. 11, n. 5, p. 4858-4874, 2011. DOI: $10.3390 / \mathrm{s} 110504858$.

FREITAS, W. A. de; CARVALHO, J. de A.; BRAGA R. A.; ANDRADE M. J. B. de.; Manejo da irrigação utilizando sensor da umidade do solo alternativo. Revista Brasileira de Engenharia Agrícola e Ambiental, Campina Grande, v. 16, n. 3, p. 268 - 274, 2012. DOI: 10.1590/s141543662012000300006 .

GOMES, F. H. F.; CUNHA, F. N.; FILHO, L. C. L.; VIDAL, V. M.; SOARES, F. A. L.; TEIXEIRA, M. B. Calibração de um sensor de umidade do solo de baixo custo. Revista Brasileira de Agricultura Irrigada, Fortaleza, v.11, n.4, p.1509-1516, 2017. DOI: 10.7127/ rbai.v11n400605.

JIMÉNEZ, A. L. A. C.; ALMEIDA, C.D.G.C.; SANTOS JÚNIOR, J.A.; MORAIS, J.E.F.; ALMEIDA, B.G.; ANDRADE, F.H.N. Accuracy of capacitive sensors for estimating soil moisture in northeastern Brazil. Soil \& Tillage Research, v. 195, p. 104413, 2019. DOI: 10.1016/j.still.2019.104413.

LEÃO, R. A. de O.; TEIXEIRA, A. S.; CANAFÍSTULA, F. J. F.; MESQUITA, P. E. G.; COELHO, S. de L. Desenvolvimento de um dispositivo eletrônico de calibração de sensores de umidade do solo. Revista Engenharia Agrícola, Jaboticabal, v. 27, n.1, p.294-303, 2007. DOI: 10.1590/s010069162007000100024.

MIRANDA, J.H.; PIRES, R.C.M. Irrigação. Piracicaba: SBEA, v.1, p.410, (Série Engenharia Agrícola), 2001.

MIRANDA, F.R. de; SANTANA, M.G.S. de; SOUZA, C.C.M. de; OLIVEIRA, C.H.C. de. 
Calibração do sensor dielétrico $\mathrm{ECH} 2 \mathrm{O}$ em dois tipos de solo. Revista Ciência Agronômica, v.38, n.3, p.317-321, 2007.

MACEDO, A. B. M.; MIRANDA, F. D. de; GOMES FILHO, R. R.; TEIXEIRA, A. dos S.; CAVALCANTE JÚNIOR, J. A. H.; ARAÚJO, H. D. de. Desempenho de um sistema de irrigação automatizado através da tensão de água no solo. Revista Brasileira de Agricultura Irrigada, v.4, p.78-81, 2010. DOI: $10.7127 /$ rbai.v4n200410.

NAVROSKI, M. C.; ARAÚJO, M. M.; PEREIRA, M. O. FIOR, C. S.; Influêcia do polímero hidroretentor nas características do substrato comercial para produção de mudas florestais. Interciência, [S.1.], v.41, n.5, p. 357-361, 2016.

OLIVEIRA, C.A.S. Determinação da tensão de água em solo agrícola usando um sensor de dissipação de calor. Pesquisa Agropecuária Brasileira, Brasília, v.34, n.8, p.1.417-1.425, 1999. DOI: $10.1590 / \mathrm{s} 0100-$ 204x1999000800014.

PIZETTA, S. C.; RODRIGUES, R. R.; PEREIRA, G. M.; PACHECO, F. E. D.; VIOLA, M. R.; LIMA, L. A. Calibração de um sensor capacitivo para estimativa da umidade em três classes de solos. Irriga, v. 22, n. 3, p. 458 - 468, 2017. DOI: 10.15809/irriga.2017v22n3p458-468.
PREVEDELLO, C.L.; LOYOLA， J.M.T. Efeito de polímeros hidroretentores na infiltração da água no solo. Scientia Agraria, Curitiba, v.8, n.3, p.313-317, 2007. DOI: 10.5380/rsa.v8i3.

8592.

BENEDÍ, J. A.; MUÑOZ-CARPENA, R. Soil-water-solute process characterization: an integrated approach. Florida: CRC Press, 787

p.

2005.

RUELLE， P., LAURENT, J.P. CS616 (CS615) water content reflectometers. In: Evett, S.R., Heng, L.K., Moutonnet, P., Nguyen, M.L. (Eds.), Field Estimation of Soil Water Content: A Practical Guide to Methods, Instrumentation, and Sensor Technology. IAEA-TCS-30. International Atomic Energy Agency, Vienna, Austria, p. 1018-5518, 2008.

TAN, W.Y.; THEN, Y.L.; LEW, Y.L.; TAY, F.S. Newly calibrated analytical models for soil moisture content and $\mathrm{pH}$ value by lowcost YL-69 hygrometer sensor. Measurement, [S.1.], v.134, p. 166-178, 2019. DOI: $\quad 10.1016 /$ j.measurement.2018.10.071.

WILLMOTT, C.J. On the validation of models. Physical Geography, [S.1.], v.2, n.2, p. 184-194, 1981. DOI: 10.1080/02723646.1981.10642213. 